\section{The Dilemma of Higher Education Reform in the United States}

\section{By Lionel S. Lewis and Philip G. Altbach}

Lionel S. Lewis is professor of sociology at the State University of New York at Buffalo. Philip G. Altbach is J. Donald Monan SJ professor of higher education at Boston College. Address for Dr. Lewis: Department of Sociology, Park Hall, SUNY at Buffalo, Buffalo, NY 14260.

$\mathrm{T}$ here has been an unremitting clamor from many about reforming undergraduate education in America. The professoriate is not unmindful of this din. Yet, it seems, little is done to improve the undergraduate curriculum. This is not as inexplicable as it appears, and we will try to explain why it is so.

Reform can mean many things. In the broadest sense, it refers to improving or changing for the better, and all parties would surely agree that they have this in mind. Still, there are other meanings of "reform." It refers to eliminating faults, abuses, or evil ways. When looked at in this way, most academics do not believe that there are serious faults, abuses, or evils that need to be fixed. And even those who do not deny that there are significant problems, might not agree on what they are. A considerable part of the problem is that the cries for reform come from top administrators who are faced with budgetary problems and the occasional wrath of legislators or editorial writers, or from a very small but influential group of "critics" who have access to the media. The fact is that there is very little demand for change from the grass roots. When asked by pollsters, consumers of higher education, students generally say they are happy with their education. Most parents, although unhappy about the high cost of a college degree, have no basic gripes about academe. We have found that the vast majority of professors are generally satisfied with conditions on campus and with the overall focus of the curriculum and of their teaching.

\section{Most academics do not believe that there are serious faults, abuses, or evils that need to be fixed.}

Reform means different things to different constituencies.

- Administrators see reform as more efficient delivery of educational services, especially teaching. Professors, they contend, should teach more students in larger classes. More part-timers should be hired because they are less expensive and more easily fired. There should be more accountability and measurement of teaching, research, and other campus activities.

- State legislators see reform as more governmental control over campuses and as increased efficiency so that state budgetary allocations can be further slashed.

- Editorialists and off-campus pundits generally have an ideological ax to grind. Critics from the right such as Charles J. Sykes and Dinesh D'Souza see the campuses has hotbeds of radicalism and dissent, and argue that professors are a lazy bunch generally committed to subverting the youth. The critics also favor cutting campus expenditures. However, they offer the thinnest evidence to support their contentions.

We believe that the focus should be mainly on the oncampus debate since the attitudes and actions of the professoriate will have the greatest impact on the everyday realities of academic life. Its influence over the curriculum remains dominant.

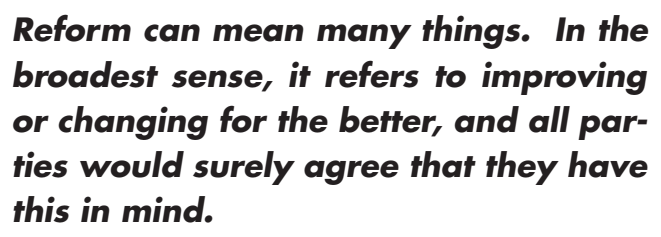

Many observers see a struggle on college and university campuses among at least three contending camps of faculty for ideological supremacy. First, there are those who insist that institutions of higher learning should be used as engines of economic growth. Second, there are those who argue that universities should be engines of social change. Third, there are those who are committed to having students learn their cultural traditions through science, mathematics, philosophy, literature, and history. Should students be taught skills that will increase their economic prospects and the country's ability to compete in the global economy or should they be taught about the values of tolerance and justice, about social inclusiveness and multiculturalism? Or is it simply enough to teach the so-called canon? There is much talk of reforming higher education, but the term clearly does not have the same meaning for all academics.

To show the diversity of faculty opinion, we analyzed the responses of nearly 3,400 full-time faculty who participated in a study conducted by the Carnegie Foundation 
for the Advancement of Teaching. In the first place, it is worth noting that many faculty do not accept the assumption that institutions of higher learning are in need of reform. Slightly less than half of those who responded were in agreement that faculty should spend more time with students outside the classroom. Those who taught in secondechelon liberal arts colleges, especially in public institutions, were most likely to believe that undergraduates should be given more attention.

It is worth noting that many faculty do
not accept the assumption that institu-
tions of higher learning are in need of
reform. Slightly less than half of those
who responded were in agreement that
faculty should spend more time with
students outside the classroom.

Over three-quarters of the professoriate felt that preparing students for work was the highest or a high priority, and an even larger number ( 80 percent) felt that strengthening the nation's capacity to compete internationally should be the highest or a high priority in a college or university education. Those who taught in the most prestigious liberal arts colleges were to a significant degree less likely to hold these views, as were humanities faculty members in all types of institutions. On the other hand, faculty in engineering, the health sciences, and in technical programs were most likely to hold this view.

A strikingly smaller proportion of the professoriate was convinced that preserving the cultural heritage should be an important goal of undergraduate education. Not surprisingly, those who taught in liberal arts colleges (especially faculty in the humanities, fine arts, and education) were most likely to express this opinion, while professors at research universities, especially those in the biological sciences and engineering, were least committed to this goal.

At the same time, almost three-fourths of the professoriate agreed that institutions of higher learning should be active in helping resolve basic social problems. Those most committed were females, most particularly social scientists who held appointments at liberal arts colleges. As we expected, those in a department of engineering or the physical sciences did not place as great an emphasis on these sorts of issues.

Faculty attitudes about multiculturalism and racial/ethnic studies in the curriculum show considerable disagreement. When asked, in the Carnegie survey, about a variety of issues relating to multiculturalism in the curriculum, more than one-third refused to take a position on the topics, preferring a neutral response. Close to one-fifth of the professoriate expressed opposition to changing the curriculum to ensure more exposure to African-Americans, women, and a variety of ethnic groups. However, 65 percent believe that the growing emphasis on multiculturalism nationwide will have a positive affect on the curriculum. These attitudes reflect the public debate on the canon and related curricular issues. The American professoriate is simply divided and perhaps even confused on some of the central curricular issues of the day. It is not surprising, therefore, that many colleges and universities have not moved decisively.

This discussion highlights several dilemmas, and shows how textured campus life is. Those at the heart of the academic enterprise, who after all still have the dominant role in shaping the curriculum and determining what happens in the classroom, are not entirely convinced that there is a "crisis" on campus, and in any case are divided about what to do about it. When asked about their views concerning the goals of the undergraduate curriculum, academics indicated a variety of opinions; these varied by the type of institution where faculty taught as well as their disciplines. Given the range of views among faculty and administrators, and the seemingly lack of consensus on campus about reform, and indeed about the goals of undergraduate education, it is unlikely that we will soon see dramatic reform on the American campus. Indeed, there might be only the smallest changes.

\section{Almost three-fourths of the professori- ate agreed that institutions of higher learning should be active in helping re- solve basic social problems.}

Yet, this conclusion could be taken as pessimistic. There was, after all, some reform of undergraduate education a decade ago when parts of the liberal arts curriculum, weakened in the turmoil of the 1960s, was restored. From history, we know that academic institutions the world over change very slowly. It is both a strength and a weakness of colleges and universities that they carefully consider options before acting on them. Academics are clearly wedded to Matthew Arnold's caveat that "no one ought to meddle with the universities, who does not know them well and love them well." 